\title{
PHOSPHORUS SOURCES RESIDUAL EFFECTS ON TIFTON 85 PRODUCTION AND NUTRITIVE VALUE CULTIVATED IN A TROPICAL WEATHERED SOIL ${ }^{1}$
}

\author{
EFEITO RESIDUAL DE FONTES DE FÓSFORO NA PRODUÇÃO E VALOR \\ NUTRICIONAL DO TIFTON 85 CULTIVADO EM SOLO TROPICAL
}

\section{Henrique Coutinho Junqueira FRANCO² ${ }^{2}$ Bernardo Melo Montes Nogueira BORGES $^{3 *}$; Sérgio Augusto Quassi de CASTRO ${ }^{3}$; Michele Xavier Vieira MEGDA ${ }^{4}$; Marcio Mahmoud MEGDA ${ }^{4}$; Alan L. GARSIDE ${ }^{5}$; Edson Luiz Mendes COUTINHO ${ }^{2}$}

1. Part of first author master's dissertation; 2. São Paulo State Univ. (Unesp), Campus Jaboticabal, Dep. of Soil Science, São Paulo, Brazil; 3. Brazilian Biorenewables National Laboratory (LNBR), Brazilian Center for Research in Energy and Materials (CNPEM), Campinas, SP, Brazil; 4. Soil and Plant Nutrition program - ESALQ/USP, Piracicaba, SP, Brazil; 5. James Cook University, Australia; *bernardo.borges@Inbr.cnpem.br

\begin{abstract}
Acid reactions and low available phosphorus in tropical soils limit forage yield. The aim was to evaluate soil chemical characteristics $\mathrm{pH}, \mathrm{P}$ and $\mathrm{Mg}$, forage nutritive values, critical soil and plant $\mathrm{P}$ levels and the residual effect of each source. The experiment was in a greenhouse with a Rhodic Haplustox, loam texture. Experimental design was a $5 \times 4$ factorial with five replicates which phosphate fertilizers were triple superphosphate, reactive rock phosphates Gafsa and Arad, and fused magnesium phosphate powder and coarse, applied at rates of 30,60, 90 and $120 \mathrm{mg} \mathrm{kg}^{-1} \mathrm{P}$ and a control treatment without $\mathrm{P}$. The effectiveness of rock phosphates increased due to their residual effect. The coarse fused magnesium phosphate resulted in the lowest efficiency. The P critical level in soil and plant were $18 \mathrm{mg} \mathrm{kg}^{-1}$ and $2.4 \mathrm{~g} \mathrm{~kg}^{-1}$, respectively. The increase of phosphorus rates provided an increase in crude protein content.
\end{abstract}

KEYWORDS: Pasture. Phosphate rock. Critical level. Bermudagrass.

\section{INTRODUCTION}

Tifton 85 (Cynodon spp.) is a grass that, when properly managed, constitutes an alternative to intensive production systems. It is a subtropical climate forage, that adapted to tropical conditions with no adverse consequences (SINCLAIR et al., 2003), presenting a great production potential under tropical climate (SOHM et al., 2014). Reasons why it was grouped amongst the most demanding soil fertility forages (WERNER et al., 1996). Demanding special attention related to the issue, highlighting phosphorus (P) as a major problem, especially in weathered soils (SANCHES; LOGAN, 1992), at present, information regarding Tifton 85 nutritional requirements in tropical conditions are still scarce.

In order to correct the soil deficiency, it is necessary to supply the nutrient utilizing fertilizers, but, unlike other sources P-fertilizers present different solubility and consequently different availability what can influence its efficiency in specific conditions.

Rock phosphates, for example, feature low water solubility or insoluble, fused magnesium phosphates (FMP) are another example, although this product is not water soluble, it presents a high solubility in neutral ammonium citrate and citric acid. Solubility of this fertilizers are not only influenced by their chemical characteristics but also physical, the smaller the particle size the greater will be the contact with the soil, increasing $\mathrm{P}$ release from these sources (TIECHER et al., 2014).

Phosphorus sources, application methods and soil management, might impact on fertilizer contact with the soil. Determining this way different reaction degrees of the phosphate fertilizer, affecting nutrient availability and root distribution in soil profile (WALKER et al., 2012; KNOX et al., 2014).

Another problem is the amount of phosphate required to correct the fertility in weathered soils considering the limited world phosphate supply and (COOPER et al., 2011), associated to an increase in costs of fertilizers, justifying studies to optimize the use efficiency of alternative phosphate sources. On one hand, there are the variations as for the nature and the solubility of the rock and industrialized phosphates, and, on the other hand, the interaction with edaphic components that sharply interfere on $\mathrm{P}$ availability to plants (PROCHNOW et al., 2003).

Nevertheless, it is necessary to establish more precise criteria for $\mathrm{P}$ recommendation. Thus the possibility to apply rock phosphates at relatively 
low cost has been emphasized as a viable alternative to supplement $\mathrm{P}$ demand to the crops in tropical highly weathered soils (FAGERIA; MOREIRA; CASTRO, 2011; GUEDES et al., 2012; WALKER et al., 2012; KNOX et al., 2014; TIECHER et al., 2014; BARBOSA et al., 2015; BUSTAMANTE et al., 2016).

The aim of this work was to evaluate soil chemical characteristics $\mathrm{pH}, \mathrm{P}$ and $\mathrm{Mg}$. $\mathrm{P}, \mathrm{Mg}$, and crude protein content were determined in the shoot and the data was used to set the critical P level in the soil and plant, dry matter yield and evaluated the residual effect of each source, expecting that alternative sources would be as efficient as triple superphosphate.

\section{MATERIAL AND METHODS}

The experiment was conducted in a greenhouse located at the Sao Paulo State, Brazil (21 14 '05"S 48 17'09'W), 615 asl, utilizing pots (diameter $=0.22 \mathrm{~m}$; height $=0.2 \mathrm{~m}$ ) containing 2.8 $\mathrm{kg}$ of soil collected from a Rhodic Haplustox loam texture (SOIL SURVEY STAFF, 2014), presenting the following chemical characteristics in the arable layer $(0-0.2 \mathrm{~m})$ : $\mathrm{pH}\left(\mathrm{CaCl}_{2}\right)=3.9$; Organic Matter $=$ $15 \mathrm{~g} \mathrm{~kg}^{-1}$; $\mathrm{P}$ (resin) $=3 \mathrm{mg} \mathrm{kg}^{-1} ; \mathrm{K}=0.06 \mathrm{cmol}_{\mathrm{c}} \mathrm{kg}^{-1}$;
$\mathrm{Ca}=0.4 \mathrm{cmol}_{\mathrm{c}} \mathrm{kg}^{-1} ; \mathrm{Mg}=0.2 \mathrm{cmol}_{\mathrm{c}} \mathrm{kg}^{-1} ; \mathrm{H}+\mathrm{Al}=$ $5.8 \mathrm{cmol}_{\mathrm{c}} \mathrm{kg}^{-1} ; \mathrm{CEC}=6.46 \mathrm{cmol}_{\mathrm{c}} \mathrm{kg}^{-1}$ and base saturation $=10 \%$.

Treatments were arranged in a complete randomized design in a factorial scheme $5 \times 4$ (five $P$ sources and four $P$ rates), with five replicates. A control treatment without application of $\mathrm{P}$ was included. The $\mathrm{P}$ sources evaluated were: Triple superphosphate - TS $\left(42.1 \% \mathrm{P}_{2} \mathrm{O}_{5} ; 10 \% \mathrm{Ca}\right)$; Arad rock phosphate $\left(34.33 \% \quad \mathrm{P}_{2} \mathrm{O}_{5}\right)$; Gafsa rock phosphate $\left(29.1 \% \quad \mathrm{P}_{2} \mathrm{O}_{5}\right)$; thermo-magnesium phosphate powder - FMP-powder $\left(18 \% \mathrm{P}_{2} \mathrm{O}_{5} ; 9 \%\right.$ $\left.\mathrm{Mg} ; 20 \% \mathrm{Ca} ; 25 \% \mathrm{SiO}_{4}\right)$; and fused magnesium phosphate coarse - FMP-coarse $\left(18 \% \mathrm{P}_{2} \mathrm{O}_{5} ; 9 \% \mathrm{Mg}\right.$; 20\% Ca; 25\% $\mathrm{SiO}_{4}$ ). Applied $\mathrm{P}$ rates were: 30; 60; 90 and $120 \mathrm{mg} \mathrm{kg}^{-1}$ of $\mathrm{P}$ and a control treatment without $\mathrm{P}$, it was taken as basis for calculating the amount of total $\mathrm{P}$ of each source.

The phosphate fertilizers presented different solubility (Table 1) and the following physical characteristics: TS with $100 \%$ passing through the $2-\mathrm{mm}$ sieve, and $50 \%$ passing through $0.3 \mathrm{~mm}$ sieve; FMP-powder $80 \%$ passing through $0.15 \mathrm{~mm}$ sieve; FMP-coarse $100 \%$ passing through $0.84 \mathrm{~mm}$ sieve and Gafsa and Arad rock phosphates with $100 \%$ passing through $4.8 \mathrm{~mm}$ sieve and $80 \%$ passing through the $2.8 \mathrm{~mm}$ sieve.

Table 1. Phosphate fertilizers solubility in citric acid (2\%) in a 1:100 ratio and water $\left(\mathrm{H}_{2} \mathrm{O}\right)$.

\begin{tabular}{|c|c|c|c|}
\hline Phosphorus sources & Total $\% \mathrm{P}_{2} \mathrm{O}_{5}$ & $\begin{array}{l}\text { Citric acid }(2 \%) \\
1: 100\end{array}$ & $\mathrm{H}_{2} \mathrm{O}$ \\
\hline & & \multicolumn{2}{|c|}{ - $\% \mathrm{P}_{2} \mathrm{O}_{5}$ soluble } \\
\hline Triple superphosphate & 41 & 100 & 90 \\
\hline FMP coarse & 18 & 92 & 0 \\
\hline FMP powder & 18 & 92 & 0 \\
\hline Arad & 34 & 35 & 0 \\
\hline Gafsa & 29 & 41 & 0 \\
\hline
\end{tabular}

FMP - Fused magnesium phosphate

Soil acidity correction was carried out with a liming application to increase soil base saturation to $60 \%$. The, the lime rate utilized was defined in an incubation pre-experiment, in which the ratio between base saturation and lime rates was obtained. The soil corrective was thoroughly mixed through the total volume of the soil in each pot and, $450 \mathrm{~mL}$ of deionized water was added, with the objective to maintain water holding capacity of the soil at $80 \%$. The soil was left incubating for 20 days. After this period, soil from each pot was air dried and sieved, proceeding the application of the phosphorus fertilizers and basic fertilization.

Basic fertilization, performed in all pots including control treatments, constituted of: $\mathrm{N}=60$ $\mathrm{mg} \mathrm{kg}{ }^{-1}$ (ammonium nitrate), $\mathrm{K}=150 \mathrm{mg} \mathrm{kg}{ }^{-1}$ (potassium chloride), $\mathrm{S}=62 \mathrm{mg} \mathrm{kg}{ }^{-1}$ (potassium sulfate), $\mathrm{B}=0.5 \mathrm{mg} \mathrm{kg}^{-1}$ (boric acid), $\mathrm{Cu}=0.5 \mathrm{mg}$ $\mathrm{kg}^{-1}$ (coper sulfate) and $\mathrm{Zn}=3.0 \mathrm{mg} \mathrm{kg}^{-1}$ (zinc sulfate). The products were dissolved in $100 \mathrm{~mL}$ distilled water, applied as solution in the total volume of the soil with manual homogenization. After this period, $300 \mathrm{~g}$ soil samples of each treatment were collected, and chemical analysis was performed to determine soil fertility.

Tifton 85 (Cynodon spp.) was planted by vegetative propagation, utilizing four stolons of 0.1 $\mathrm{m}$ long, with two buds each. Fifteen days after planting a standardization clipping at $0.1 \mathrm{~m}$ from soil surface was carried out. During experimental period three manual shoot harvests were conducted (scissors were utilized) at $0.1 \mathrm{~m}$ from soil surface, in 
30-days intervals. After each growth (including standardization clipping) topdressing was performed applying $160 \mathrm{mg} \mathrm{kg}^{-1}$ of $\mathrm{N}$ and $50 \mathrm{mg} \mathrm{kg}^{-1}$ of $\mathrm{K}$, as ammonium nitrate and potassium chloride, respectively. Fertilization was performed in all treatments, including control, with the objective to evaluate residual $\mathrm{P}$ effect on the second and third harvest. During experimental period, all pots were watered daily with distilled water. The amount of water added was determined by the daily weighting of the pots.

After the first harvest, two replicates were deactivated to proceed with soil sampling. At the end of the third harvest soil samples were collected from each treatment determine $\mathrm{pH}$ values in a calcium chloride solution $\left(0.01 \mathrm{~mol} \mathrm{~L}^{-1}\right), \mathrm{P}$ and $\mathrm{Mg}$ available in the soil were extracted utilizing the ionexchange resin procedure and determined by colorimetric method.

Subsequent to the harvests, shoots were washed, and oven dried at $65{ }^{\circ} \mathrm{C}$. Dried, materials were weighted in order to quantify dry matter production of each pot. Dry shoots were ground and analyzed for total $\mathrm{N}-\mathrm{Kj}$ eldahl, $\mathrm{Mg}$ and $\mathrm{P}$ content by nitro-perchloric extraction. The crude protein (C.P.) content was calculated by multiplying total $\mathrm{N}$ content $\left(\mathrm{g} \mathrm{kg}^{-1}\right)$ by the constant 0.625 , expressed in $\%$ in shoot dry matter.

Using the evaluated variables, we attempted to established critical P levels for the plant and soil.

The treatments' effects on $\mathrm{P}$ sources and rates were submitted to a two-way ANOVA utilizing $\mathrm{F}$ test. Posteriorly for the significant causes of variation a Tukey test $(P \leq 0.05)$ was applied to compare source effect. When significant, the interaction source $\mathrm{x}$ rate was deployed for each variable separately and regression calculations performed utilizing the statistical package SigmaPlot version 11.0 (Systat Software, San Jose, CA).

\section{RESULTS AND DISCUSSION}

\section{Forage dry matter yield}

Phosphate fertilization promoted an increase in Tifton 85 shoot dry matter yield during the whole experimental period (Fig. 1). The increase in dry matter yield when utilizing phosphate fertilizers has been mentioned by several authors (HILLARD; HABY; HONS, 1992; GUEDES et al., 2012; TIECHER et al., 2014; FAN et al., 2016) in forages, thus re-enforcing the importance of $\mathrm{P}$ in the nutrition of forage species.
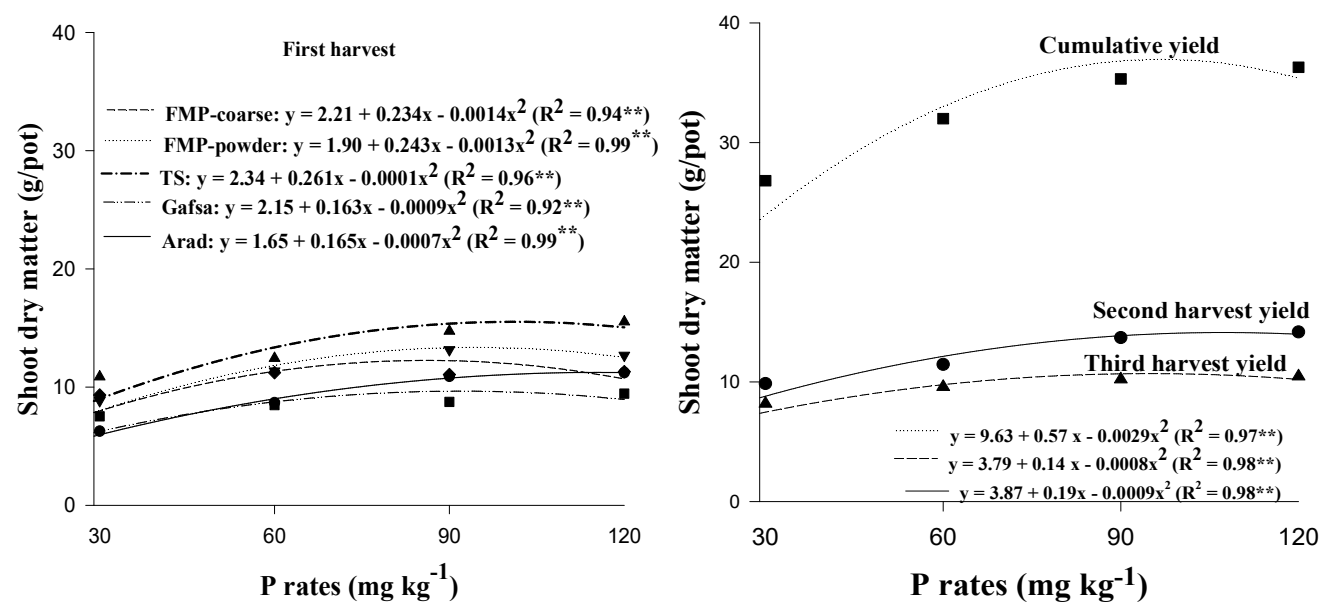

Figure 1. Effect of $P$ sources and rates on Tifton 85 shoot dry matter yield during experimental period.

The initial growth of the forage was superior for TS compared to the other sources, contrary results were found in the literature, in which, FMPs promoted an initial effect similar or at times superior to the TS (MOREIRA et al., 2014; BARBOSA et al., 2015). Although soil acidity and the incorporation of fertilizers into the soil increase rock phosphates solubilization (BUSTAMANTE et al., 2016), it was not able to supply enough $P$ in order to positively affect forage dry matter yield in the first harvest. Arad rock phosphate presented higher efficiency on $\mathrm{P}$ utilization by grasses when cultivated in an Oxisol, indicating favorable and residual conditions for reactive phosphate solubilization (RAMOS et al., 2009).

The residual effect of the reactive rock phosphates is due to its gradual dissolution, that contributes to a lower P adsorption (KNOX et al., 2014), with an important residual effect (GUEDES et al., 2012). As a result of its geological origin, Arad releases the $\mathrm{P}$ from its crystallographic structure in a shorter period of time than the 
Brazilian rock phosphates. The technical recommendations for the use of reactive rock phosphates possess some uncertainties, there is a consensus that more soluble phosphates provide greater response in the year of application, while rock phosphates are less efficient initially (ROSOLEM; MERLIN, 2014).

The lowest residual effect of the coarse FMP on Tifton 85 dry matter yield in the second harvest, differ from a series of studies in the literature (FAGERIA; BARBOSA FILHO, 2007; FAGERIA; MOREIRA; CASTRO, 2011; MOREIRA et al., 2014; BARBOSA et al., 2015) which FMP presented a superior residual effect compared to a soluble source (TS). As for FMPs, the process of $\mathrm{P}$ dissolution is slow, since it depends on chemical reactions with the soil (BUSTAMANTE et al., 2016).
Cumulative dry matter yield on TS and FMP-powder were similar. The FMP in powder, presented a residual effect similar to TS; FMP coarse resulted in a lower recovery of $\mathrm{P}$ residual, the contact to soil is minimized causing a non-optimal condition to $\mathrm{P}$ solubilization (FAGERIA; BARBOSA FILHO, 2007; BUSTAMANTE et al., 2016).

\section{Soil and forage attributes}

Phosphorus level in the soil decreased along the experimental period (Fig. 2), similar results with different forages species were reported (KUWAHARA et al., 2016), soil P levels significantly decreased, due to the large nutrient extraction by the forage.
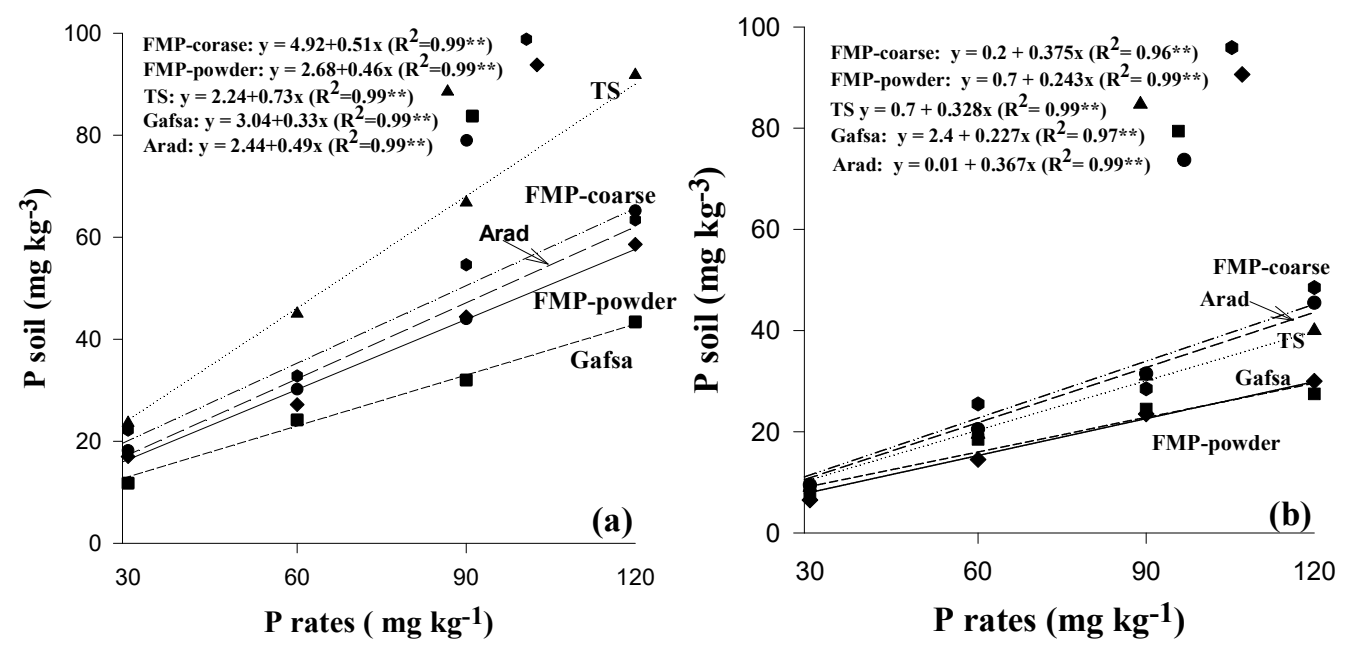

Figure 2. Effect of $P$ sources and rates on levels of $P$ soil before (a) and after (b) first harvest.

The TS was the source that promoted the highest $\mathrm{P}$ level in the soil after its application and before the planting of the crop, however, after the first harvest the soil treated with FMP-coarse presented the highest P level. Sources with high water solubility such as TS promptly provide $\mathrm{P}$ to the plants, though, in acid and weathered soils, in a short period of time after fertilizer application, $\mathrm{P}$ adsorption occurs and posterior fixation on the surface of the Fe/Al oxides (OBERSON et al., 2001) and/or precipitation as a $\mathrm{P}$ secondary mineral linked to iron and aluminum, decreases available $\mathrm{P}$ content in the soil. On the other hand, results of FMP-coarse for P soil (Fig. 2) contradicts forage yield, in which this source presented the lowest performance. This observation suggests that the result of FMP-coarse P soil availability was overestimated and, thus, it can be inferred that the anion exchange resin method extracts P from the FMP-coarse treatment not as the roots of the plants.

The Gafsa rock phosphate present $\mathrm{P}$ content value (Fig. 3a), at the first harvest, lower than the considered adequate 1.5 to $3.0 \mathrm{~g} \mathrm{~kg}^{-1} \mathrm{P}$ for Cynodon grasses (KELLING; MATOCHA, 1990; WERNER et al., 1996). In the second harvest, $P$ sources were similar on shoot $\mathrm{P}$ content and it is in the range, 1.5 to $3.0 \mathrm{~g} \mathrm{~kg}^{-1} \mathrm{P}$, considered sufficient (KELLING; MATOCHA, 1990). 

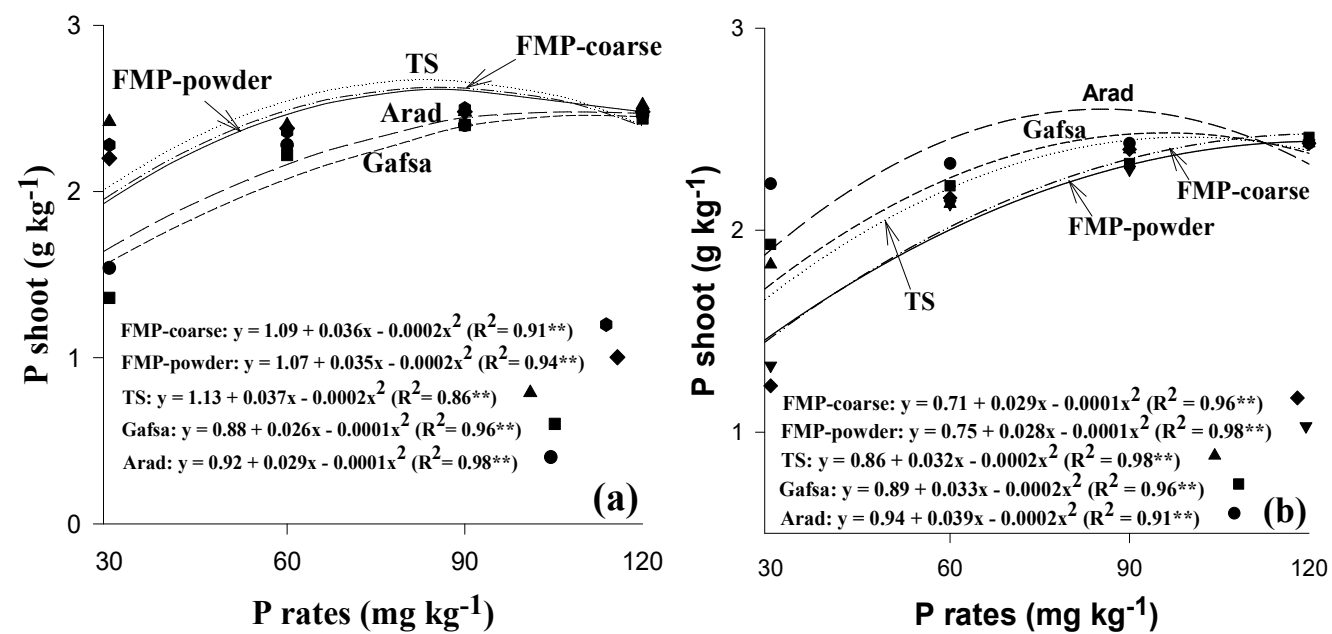

Figure 3. Effect on $P$ sources and rates on Tifton 85 shoot $P$ content in the first (a) and third (b) harvest.

Although no effect on C.P. were noticed when varying $P$ sources differences on $P$ rates were noted for the second $\left(\mathrm{y}=-0.0006 \mathrm{x}^{2}+0.105 \mathrm{x}+10.7 ; \mathrm{R}^{2}\right.$ $=0.89 ; \quad P \quad<0.001)$ and third $\quad(\mathrm{y}=-$ $\left.0.0003 \mathrm{x}^{2}+0.072 \mathrm{x}+10.05 ; \quad \mathrm{R}^{2}=0.99 ; \quad P \quad<0.001\right)$ harvest, as mentioned by Souza et al. (1999) working with Brachiaria brizantha in a low fertility soil, after a 90 days growing period, also reported that phosphorus fertilization (P rates 50, $100200 \mathrm{e}$ $300 \mathrm{mg} \mathrm{kg}^{-1}$ as TS) resulted in an increase of C.P. content on forage shoot.

\section{Phosphorus critical level}

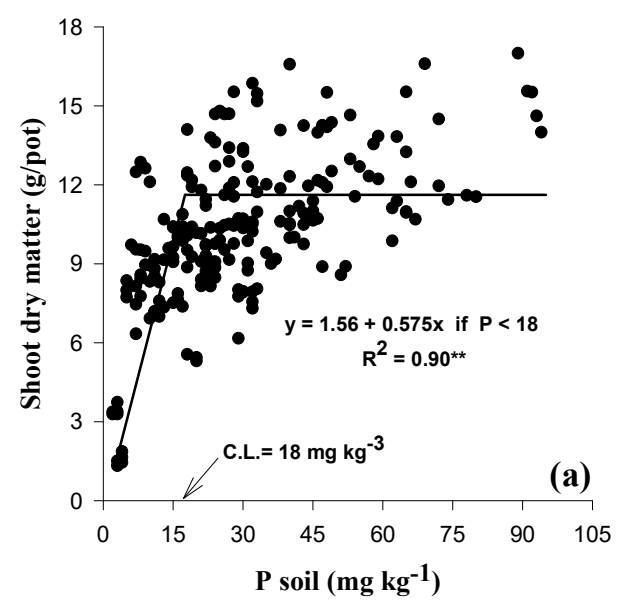

Figure 4. Soil (a) and Plant (b) phosphorus critical level.

The $\mathrm{P}$ shoot content associated to the soi $\mathrm{P}$ level was $2.4 \mathrm{~g} \mathrm{~kg}^{-1} \mathrm{P}$ which lies in the range $1.5-$ $3.0 \mathrm{~g} \mathrm{~kg}^{-1}$ considered adequate for Cynodon cultivars (WERNER et al., 1996) and, close to the critical level of $2.2 \mathrm{~g} \mathrm{~kg}^{-1} \mathrm{P}$ for Coastal bermudagrass (HILLARD; HABY; HONS, 1992).
The soil P critical level corresponded to 18 $\mathrm{mg} \mathrm{kg}{ }^{-1} \mathrm{P}$ (Fig. 4). This value represents soil $\mathrm{P}$ level that above it, yields' response to $\mathrm{P}$ fertilization is probably low, $\mathrm{P}$ critical level. This value is slightly over the superior limit $\left(7-15 \mathrm{mg} \mathrm{kg}^{-1}\right)$ of the low $\mathrm{P}$ soil class, which was stablished in calibration insights with annual crops in the field (WERNER et al., 1996). However, when considering the values proposed by Kelling and Matocha (1990) ranging from 3 to $21 \mathrm{mg} \mathrm{kg}^{-1}$, it might be inferred that the critical level obtained in our study lies in the praised range aiming to execute a phosphorus fertilization with precision and sustainability.

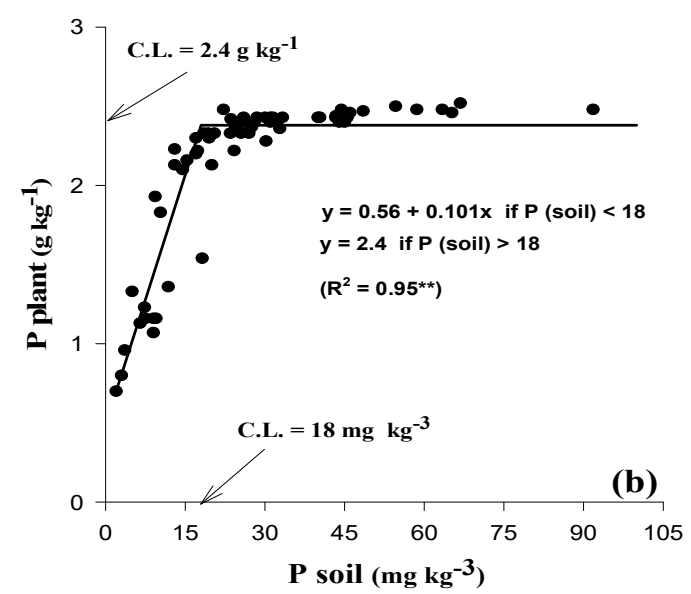

\section{CONCLUSIONS}

Phosphorus fertilization promoted an increment on Tifton 85 shoot dry matter yield.

The increase of rates up to $90 \mathrm{mg} \mathrm{kg}^{-1} \mathrm{P}$ presented an increase on shoot dry matter yield, 
wherein triple superphosphate (TS) was the source with the highest agronomic efficiency.

The efficiency of reactive phosphates (Arad and Gafsa) increased when it was considered its residual effect, whereas the coarse granulometry of the FMP resulted in a lower agronomic efficiency than the FMP-powder.

The increment on $\mathrm{P}$ rates provided increase on $\mathrm{P}$ content and crude protein in Tifton 85 shoot.
The $\mathrm{P}$ critical level in the soil and plant was $18 \mathrm{mg} \mathrm{kg}^{-1}$ and $2.4 \mathrm{~g} \mathrm{~kg}^{-1}$, respectively.

\section{ACKNOWLEDGEMENTS}

To the estimate Professor Dr. Luiz Roberto de Andrade Rodrigues (In memorian) for his suggestions during the conduction of the experiment.

RESUMO: Reações ácidas e baixo fósforo disponível em solos tropicais limitam a produção de forragem. O objetivo foi avaliar as características químicas do solo $\mathrm{pH}, \mathrm{P}$ e $\mathrm{Mg}$, valores nutritivos das forragens, níveis críticos de $\mathrm{P}$ no solo e nas plantas e o efeito residual de cada fonte. O experimento foi realizado em casa de vegetação com Latossolo vermelho distrófico, textura média. O delineamento experimental foi inteiramente casualisado em fatorial 5 x 4, com cinco repetições cujos adubos fosfatados eram superfosfato triplo, fosfatos de rocha reativa Gafsa e Arad e fosfato de magnésio em pó e grosso, aplicados nas doses de 30, 60, 90 e $120 \mathrm{mg} \mathrm{kg}^{-1}$ de $\mathrm{P}$ e um tratamento controle sem P. A eficácia dos fosfatos rochosos aumentou devido ao seu efeito residual. $\mathrm{O}$ fosfato de magnésio fundido grosso resultou na menor eficiência. $\mathrm{O}$ nível crítico de $\mathrm{P}$ no solo e na planta foi de $18 \mathrm{mg} \mathrm{kg}^{-1}$ e $2,4 \mathrm{~g} \mathrm{~kg}^{-1}$, respectivamente. $\mathrm{O}$ aumento das taxas de fósforo proporcionou um aumento no teor de proteína bruta.

PALAVRAS-CHAVE: Pastagens. Rocha fosfática. Nível crítico. Bermudagrass.

\section{REFERENCES}

BARBOSA, T. M. B.; SANTOS, J. Z. L.; TUCCI, C. A. F.; DA SILVA, S. V.; CARDOSO, A. A. D. S.; PEREIRA, B. F. F. Phosphorus Sources: Effects on Growth and Phosphorus Fractions of Curauá ( Ananas erectifolius L. B. Smith). Communications in Soil Science and Plant Analysis, v. 46, n. 10, p. 1200-1211, 2015. Disponível em: <http://www.tandfonline.com/doi/full/10.1080/00103624.2015.1033531>.

BUSTAMANTE, M. A.; CEGLIE, F. G.; ALY, A.; MIHRETEAB, H. T.; CIACCIA, C.; TITTARELli, F. Phosphorus availability from rock phosphate: Combined effect of green waste composting and sulfur addition. Journal of Environmental Management, v. 182, p. 557-563, 2016. Disponível em: $<$ http://dx.doi.org/10.1016/j.jenvman.2016.08.016>.

COOPER, J.; LOMBARDI, R.; BOARDMAN, D.; CARLIELL-MARQUET, C. The future distribution and production of global phosphate rock reserves. Resources, Conservation and Recycling, v. 57, n. January, p. 78 86, 2011. Disponível em: <http://dx.doi.org/10.1016/j.resconrec.2011.09.009>.

FAGERIA, N. K.; BARBOSA FILHO, M. P. Dry-Matter and Grain Yield, Nutrient Uptake, and Phosphorus Use-Efficiency of Lowland Rice as Influenced by Phosphorus Fertilization. Communications in Soil Science and Plant Analysis, v. 38, n. 9-10, p. 1289-1297, 2007. Disponível em:

$<$ http://www.tandfonline.com/doi/abs/10.1080/00103620701328537>.

FAGERIA, N. K.; MOREIRA, A.; CASTRO, C. Response of Soybean to Phosphorus Fertilization in Brazilian Oxisol. Communications in Soil Science and Plant Analysis, v. 42, n. 22, p. 2716-2723, 2011. Disponível em: $<$ http://www.tandfonline.com/doi/full/10.1080/00103624.2011.622819>.

FAN, J.-W.; DU, Y.-L.; WANG, B.-R.; TURNER, N. C.; WANG, T.; ABBOTT, L. K.; STEFANOVA, K.; SIDDIQUE, K. H. M.; LI, F.-M. Forage yield, soil water depletion, shoot nitrogen and phosphorus uptake and concentration, of young and old stands of alfalfa in response to nitrogen and phosphorus fertilisation in a semiarid environment. Field Crops Research, v. 198, p. 247-257, 2016. Disponível em: $<$ http://linkinghub.elsevier.com/retrieve/pii/S0378429016302714>. 
GUEDES, E. M. S.; FERNANDES, A. R.; LOBATO, A. K. da S.; GUEDES, R. S.; DE ÁVILA, W. S.; DA SILVA, S. P. Natural phosphate and liming improves phosphorus extraction in two tropical grasses grown in degraded Amazon soil. Journal of Food, Agriculture and Environment, v. 10, n. 3-4, p. 1165-1168, 2012.

HILLARD, J. B.; HABY, V. A.; HONS, F. M. Effects of limestone and phosphorus on nutrient availability and coastal bermudagrass yield on an Ultisol. Communications in Soil Science and Plant Analysis, v. 23, n. 1-2, p. 175-188, jan. 1992. Disponível em: <http://www.tandfonline.com/doi/abs/10.1080/00103629209368580>.

KELLING, K. A.; MATOCHA, J. E. Plant analysis as an aid in fertilizing forage crops. In: WESTERMAN, R. L. (Ed.). Soil testing and plant analysis. Madison, WI: Soil Science of America, 1990. p. 603-643. https://doi.org/10.2136/sssabookser3.3ed.c23

KNOX, O. G. G.; ACHARA, O. N.; PARKER, J.; ALEGRIA, R.; WALKER, R. L.; EDWARDS, A. C.; WATSON, C. A. Investigating the Use of Silage Effluent to Improve Available Phosphorus from Gafsa Phosphate Rock. Communications in Soil Science and Plant Analysis, v. 45, n. 3, p. 332-346, 4 fev. 2014. Disponível em: <http:/www.tandfonline.com/doi/abs/10.1080/00103624.2013.857412>.

KUWAHARA, F. A.; SOUZA, G. M.; GUIDORIZI, K. A.; COSTA, C.; MEIRELLES, P. R. de L. Phosphorus as a mitigator of the effects of water stress on the growth and photosynthetic capacity of tropical C4 grasses. Acta Scientiarum. Agronomy, v. 38, n. 3, p. 363, 24 jun. 2016. Disponível em: $<$ http://periodicos.uem.br/ojs/index.php/ActaSciAgron/article/view/28454>.

MOREIRA, A.; SFREDO, G. J.; MORAES, L. a. C.; FAGERIA, N. K. Agronomic Efficiency of Two Types of Lime and Phosphate Fertilizer Sources in Brazilian Cerrado Soils Cultivated with Soybean. Communications in Soil Science and Plant Analysis, v. 45, n. 17, p. 2319-2330, 2014. Disponível em:

$<$ http://www.tandfonline.com/doi/abs/10.1080/00103624.2014.932372>.

OBERSON, A.; FRIESEN, D. K.; RAO, I. M.; BÜHLER, S.; FROSSARD, E. Phosphorus Transformations in an Oxisol under contrasting land-use systems: The role of the soil microbial biomass. Plant and Soil, v. $237, \mathrm{n}$. 2, p. 197-210, 2001. Disponível em: <http://link.springer.com/10.1023/A:1013301716913>.

PROCHNOW, L. I.; CHIEN, S. H.; TAYLOR, R. W.; CARMONA, G.; HENAO, J.; DILLARD, E. F. Characterization and Agronomic Evaluation of Single Superphosphates Varying in Iron Phosphate Impurities. Agronomy Journal, v. 95, p. 293-302, 2003. Disponível em: https://doi.org/10.2134/agronj2003.0293.

RAMOS, S. J.; FAQUIN, V.; RODRIGUES, C. R.; SILVA, C. A.; BOLDRIN, P. F. Biomass production and phosphorus use of forage grasses fertilized with two phosphorus sources. Revista Brasileira de Ciência do Solo, v. 33, n. 2, p. 335-343, abr. 2009. Disponível em:

$<$ http://www.scielo.br/scielo.php?script=sci_arttext\&pid=S0100-

06832009000200011\&lng=en\&nrm=iso\&tlng=en>. https://doi.org/10.1590/S0100-06832009000200011

ROSOLEM, C. A.; MERLIN, A. Soil phosphorus availability and soybean response to phosphorus starter fertilizer. Revista Brasileira de Ciência do Solo, v. 38, n. 5, p. 1487-1495, out. 2014. Disponível em: $<$ http://www.scielo.br/scielo.php?script=sci_arttext\&pid=S0100-

06832014000500014\&lng=en\&nrm=iso\&tlng=en>. https://doi.org/10.1590/S0100-06832014000500014

SANCHES, P.; LOGAN, T. Myths and science about the chemistry and fertility of soils in the tropics. In: LAL, R.; SANCHES, P. (Ed.). Myths and science of soils of the tropics. Madison: Soil Science Society of America, 1992. p. 35-46. https://doi.org/10.2136/sssaspecpub29.c3

SINCLAIR, T. R.; RAY, J. D.; MISLEVY, P.; PREMAZZI, L. M. Growth of Subtropical Forage Grasses under Extended Photoperiod during Short-Daylength Months Mention of a Trademark or Proprietary Product Does Not Constitute a Guarantee or Warranty of the Product by the U.S. Department of Agriculture and Does Not Imply. Crop Science, v. 43, p. 618-623, 2003. Disponível em: https://doi.org/10.2135/cropsci2003.0618. 
SOHM, G.; THOMPSON, C.; ASSEFA, Y.; SCHLEGEL, A.; HOLMAN, J. Yield and quality of irrigated bermudagrass as a function of nitrogen rate. Agronomy Journal, v. 106, n. 4, p. 1489-1496, 2014. https://doi.org/10.2134/agronj 13.0580

SOIL SURVEY STAFF. Keys to soil taxonomy. Soil Conservation Service, v. 12, p. 410, 2014. Disponível em: $<$ http://www.nrcs.usda.gov/Internet/FSE_DOCUMENTS/nrcs142p2_051546.pdf>.

SOUZA, R.; PINTO, J.; SIQUEIRA, J.; RESENDE, V. Micorriza e fósforo no crescimento de Brachiaria brizantha e Stylosanthes guianensis em solo de baixa fertilidade. 1. Produção de matéria seca e proteína bruta. Pasturas Tropicales, v. 21, p. 19-23, 1999.

TIECHER, T.; OLIVEIRA, L. B.; RHEINHEIMER, D. S.; QUADROS, F. L. F.; GATIBONI, L. C.; BRUNETTO, G.; KAMINSKI, J. Phosphorus application and liming effects on forage production, floristic composition and soil chemical properties in the Campos biome, southern Brazil. Grass and Forage Science, v. 69, n. 4, p. 567-579, 2014. https://doi.org/10.1111/gfs. 12079

WALKER, R. L.; EDWARDS, A. C.; MASKELL, P.; WATSON, C. A.; REES, R. M.; KNOX, O. G. G.; STOCKDALE, E. A. The effect of co-composted cabbage and ground phosphate rock on the early growth and $\mathrm{P}$ uptake of oilseed rape and perennial ryegrass. Journal of Plant Nutrition and Soil Science, v. 175, n. 4, p. 595-603, 2012. https://doi.org/10.1002/jpln.201100124

WERNER, J. C.; PAULINO, V. T.; CANTARELLA, H.; ANDRADE, N. O.; QUAGGIO, J. A. Forrageiras. In: RAIJ, B.; CANTARELLA, H.; QUAGGIO, J. A.; FURLANI, A. M. C. (Ed.). Recomendações de adubação e calagem para o Estado de São Paulo (In Portuguese). Campinas: IAC, 1996. p. 263-273. 